\title{
Bioerosion in the carbonate budget of two Indo-Pacific reefs: La Réunion (Indian Ocean) and Mooréa (Pacific Ocean)
}

\author{
MIREILLE PEYROT-CLAUSADE, VERONIQUE CHAZOTTES \& NATALIE PARI
}

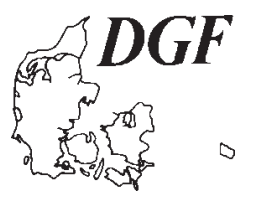

\begin{abstract}
Peyrot-Clausade, M., Chazottes, V. \& Pari, N.: Bioerosion in the carbonate budget of two Indo-Pacific reefs: La Réunion (Indian Ocean) and Mooréa (Pacific Ocean). Bulletin of the Geological Society of Denmark, Vol. 45, pp. 151-155. Copenhagen 1999-01-30. https://doi.org/10.37570/bgsd-1998-45-20
\end{abstract}

On coral reefs, products of bioerosion through the activity of micro- and macroboring organisms and grazers are particulate and dissolved carbonate. The contribution to bioerosion of the major boring and grazing species was estimated on French Polynesia and the island La Réunion. The influence of bioerosion on the calcification/dissolution budget of reefal waters and on particulate calcium carbonate fluxes was investigated. Studies on bioerosion were performed in order to assess: (a) eroding activity of grazers through the gut content analysis of echinoids and scarid parrot fish, (b) eroding activity of micro- and macroborers from experimental substrates exposed for one year, and (c) role of sponges in total bioerosion on reefal and experimental substrates. Calcification/dissolution budget was measured using the alkalinity anomaly technique, and particulate carbonate production was analysed from trapped sediments.

Key words: Bioerosion, reefs, Pacific Ocean, Indian Ocean.

M. Peyrot-Clausade \& N. Pari, Centre d'Océanologie de Marseille, DIMAR, rue Batterie des Lions, 13007 Marseille France. V. Chazottes \& N. pari, Centre Sédipal, Université d'Aix-Marseille I, 3 Place Victor Hugo, 13331 Marseille cedex France. 15 July 1998.

The object of this study is to estimate the total bioerosion in two small high-island reefs on Mooréa and La Réunion in order to appreciate the influence of geographical settings on bioerosion and to allow us to construct their $\mathrm{CaCO}_{3}$ budgets. Conclusions as to the health of the reefs may be drawn on this basis.

Data have been collected on Trou d'Eau fringing reef in La Réunion (Indian Ocean) and on Tiahura fringing and barrier reefs in Mooréa, French Polynesia (Pacific Ocean).

\section{Study areas}

La Réunion $\left(21^{\circ} \mathrm{S}, 55^{\circ} \mathrm{E}\right)$ is located $800 \mathrm{~km}$ east of Madagascar (Fig. 1). The geomorphology of Trou d'Eau reef comprises three parts from open ocean towards land: the outer reef flat or compact reef (site TR1), which is a continuous construction of corals and encrusting algae; the inner reef flat (TR2), which displays wide transversal strips of branched coral colonies alternating with narrow detrital channels perpen- dicular to the reef front; and the back reef zone, mainly biodetrital (TR3), which is the deepest part.

On Mooréa $\left(17^{\circ} \mathrm{S}, 149^{\circ} \mathrm{E}\right)$, four stations have been selected on the Tiahura reef on a transect from open ocean towards land. Three stations are on the barrier reef: one at $100 \mathrm{~m}$ from the front of the compact reef (site B1); another at $250 \mathrm{~m}$ from the front, on the flat with transverse strips (B2); and the third, B3, at 450 $\mathrm{m}$ from the front, on the flat with scattered corals. On the fringing reef, one site $(\mathrm{F})$ is located at $50 \mathrm{~m}$ from the fringing front.

\section{Eroding activity of grazers}

Echinoids and scarid fishes are the major grazers involved in bioerosion processes; the quantity of carbonate eroded from the reef framework by these populations was determined through the study of gut contents evaluated for each size class. The size frequency distributions and density data were then used to ob- 

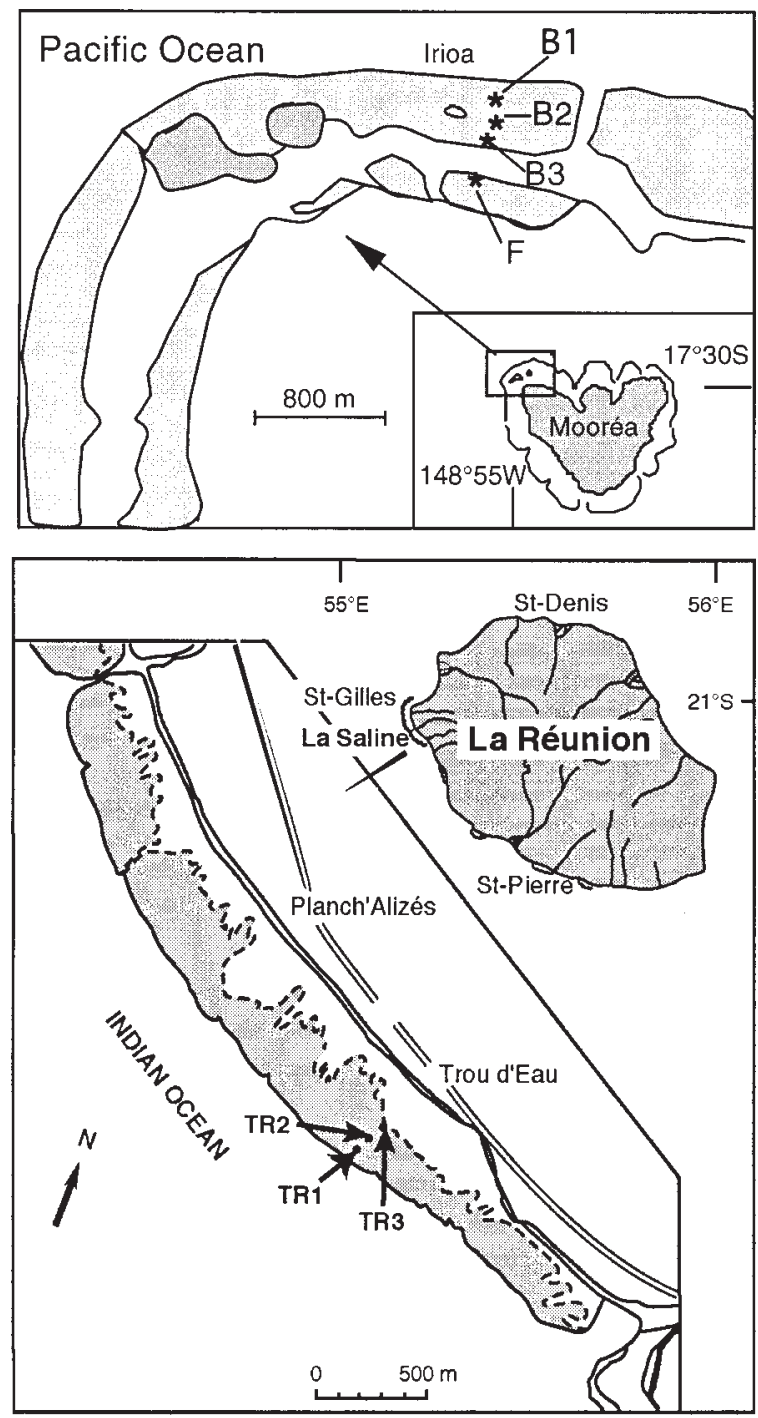

Fig. 1. Location map of the Mooréa and Trou d'Eau reef sites.

tain the mean population bioerosion (Conand, Heeb, Peyrot-Clausade \& Fontaine 1998).

On Mooréa barrier reef flat, bioerosion was estimated from 5 to $7.2 \mathrm{~kg} \mathrm{CaCO}_{3} \mathrm{~m}^{-2} \mathrm{yr}^{-1}$ for echinoids and $0.9 \mathrm{~kg} \mathrm{CaCO}_{3} \mathrm{~m}^{-2} \mathrm{yr}^{-1}$ for scarids, on the fringing reef $0.5 \mathrm{~kg} \mathrm{CaCO}_{3} \mathrm{~m}^{-2} \mathrm{yr}^{-1}$ are eroded by sea-urchins and $3.2 \mathrm{~kg} \mathrm{CaCO}_{3} \mathrm{~m}^{-2} \mathrm{yr}^{-1}$ by parrot fishes.

On La Réunion only two species of Echinometra are abundant (Conand, Chabanet, Cuet \& Letourneur 1997). The rate of bioerosion they cause decreases from the outer flat at $8.3 \mathrm{~kg} \mathrm{CaCO} \mathrm{m}^{-2} \mathrm{yr}^{-1}$ to the inner flat at $0.4 \mathrm{~kg} \mathrm{CaCO}_{3} \mathrm{~m}^{-2} \mathrm{yr}^{-1}$. The activity of scarids is very low, $0.137 \mathrm{~kg} \mathrm{CaCO}_{3} \mathrm{~m}^{-2} \mathrm{yr}^{-1}$ at a maximum. It is linked to the feeble density of scarids and their small size.

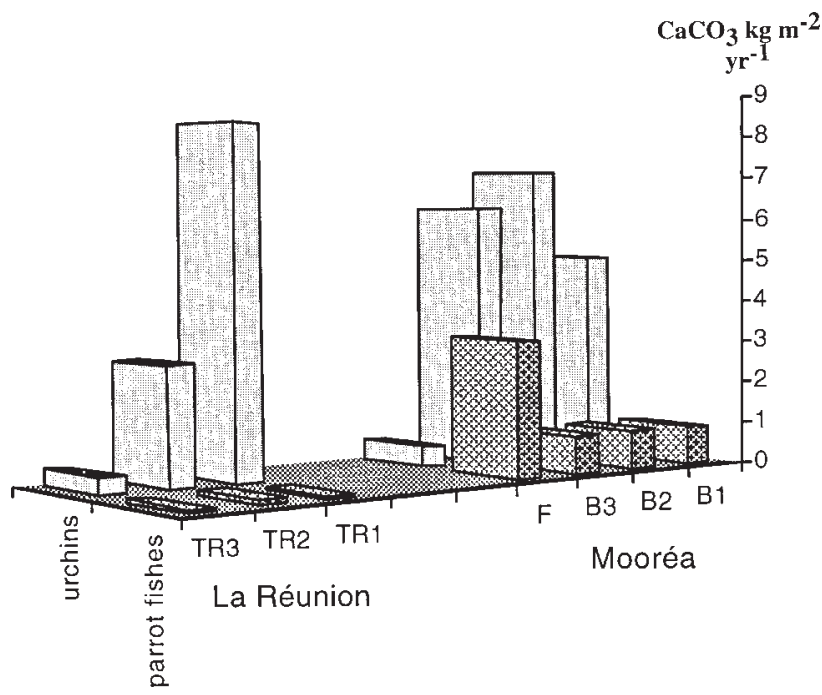

Fig. 2. Eroding activity of grazers on Mooréa and La Réunion reefs.

So, on Mooréa the maximun total erosion rate is $8.1 \mathrm{~kg} \mathrm{CaCO}_{3} \mathrm{~m}^{-2} \mathrm{yr}^{-1}$ on the barrier reef flat and 3.7 $\mathrm{kg} \mathrm{CaCO}_{3} \mathrm{~m}^{-2} \mathrm{yr}^{-1}$ on the fringing reef. In La Réunion, $8.34 \mathrm{~kg} \mathrm{CaCO}_{3} \mathrm{~m}^{-2} \mathrm{yr}^{-1}$ are eroded by grazers on the outer flat and $0.46 \mathrm{~kg} \mathrm{CaCO}_{3} \mathrm{~m}^{-2} \mathrm{yr}^{-1}$ on the inner flat (Fig. 2).

\section{Eroding activity of borers}

In order to assess the boring activity of micro- and macroborers, experimental substrate blocks cut from Porites were laid on Mooréa barrier flat in 1986, on the fringing flat in 1990 and at three sites on La Réunion in 1991 (Peyrot-Clausade, Le CampionAlsumard, Hutchings, Le Campion, Pari \& Fontaine 1995, Chazottes, Le Campion-Alsumard \& PeyrotClausade 1995). At each site on each reef a set of blocks was collected after one year of exposure. Rates of erosion by micro- and macroborers and by grazers were estimated from measurements of carbonate removal from these exposed blocks using image analysis. On Mooréa, bioerosion by microborers was 0.14 $\mathrm{kg} \mathrm{CaCO} \mathrm{m}^{-2} \mathrm{y}^{-1}$ and $0.022 \mathrm{~kg} \mathrm{CaCO}_{3} \mathrm{~m}^{-2} \mathrm{yr}^{-1}$ was eroded by macroborers. External erosion was $1.74 \mathrm{~kg}$ $\mathrm{CaCO}_{3} \mathrm{~m}^{-2} \mathrm{yr}^{-1}$. Blocks on La Réunion also showed erosion by microborers (between 0.044 and $0.066 \mathrm{~kg}$ $\left.\mathrm{CaCO}_{3} \mathrm{~m}^{-2} \mathrm{yr}^{-1}\right)$ which was higher than that by macroborers ( 0.015 to $0.034 \mathrm{~kg} \mathrm{CaCO}_{3} \mathrm{~m}^{-2} \mathrm{yr}^{-1}$ ) (Figure 2). Grazers and microborers acting in synergy caused external erosion between 2.8 and $3.2 \mathrm{~kg} \mathrm{CaCO}_{3}$ $\mathrm{m}^{-2} \mathrm{yr}^{-1}$ according to the site. 


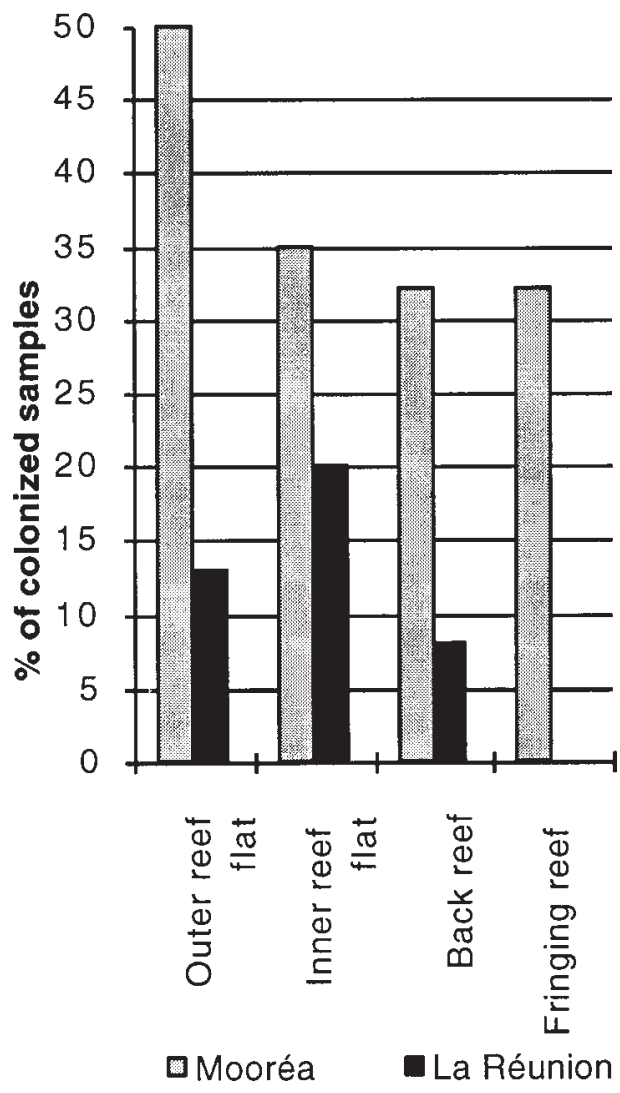

Fig. 3. Importance of boring sponges on Mooréa and La Réunion reefs.

\section{Role of boring sponges}

To estimate the biodiversity of boring sponges in the two reefs, samples were collected at different sites and in different substrates and, in order to quantify their rate of bioerosion, experiments were carried out over five years.

First results allow us to say that (1) the biodiversity is relatively low on the two reefs; seven species were collected on La Réunion and ten on Mooréa, although abundance of sponges is higher on Mooréa than on La Réunion (Fig. 3). (2) Density of clionids increases as grazing pressure decreases. (3) The most abundant species on the two reefs are Cliona vastifica and Cliothosa hancocki. (4) Their boring activities, calculated from experiments in French Polynesia, are 1 $\mathrm{kg} \mathrm{CaCO} \mathrm{m}^{-2} \mathrm{yr}^{-1}$ for Cliona vastifica and $0.5 \mathrm{~kg}$ $\mathrm{CaCO}_{3} \mathrm{~m}^{-2} \mathrm{yr}^{-1}$ for Cliothosa hancocki.

\section{Calcification/dissolution budget}

The calcium carbonate budget of coral reefs is the result of the interactions of the processes of calcification and biological degradation, and reflects the chemical properties of the seawater overlying the reefs. Net calcification was measured using the alkalinity anomaly technique (Smith \& Kinsey 1978) on the reef flat from an upstream to a downstream station.The location of the downstream station varied according to current direction. A small current drogue was used as tracer. On La Réunion reef this budget was calculated for two transects (Conand, Chobonet, Cuet, Letourneur 1998). Between the outer reef flat and the

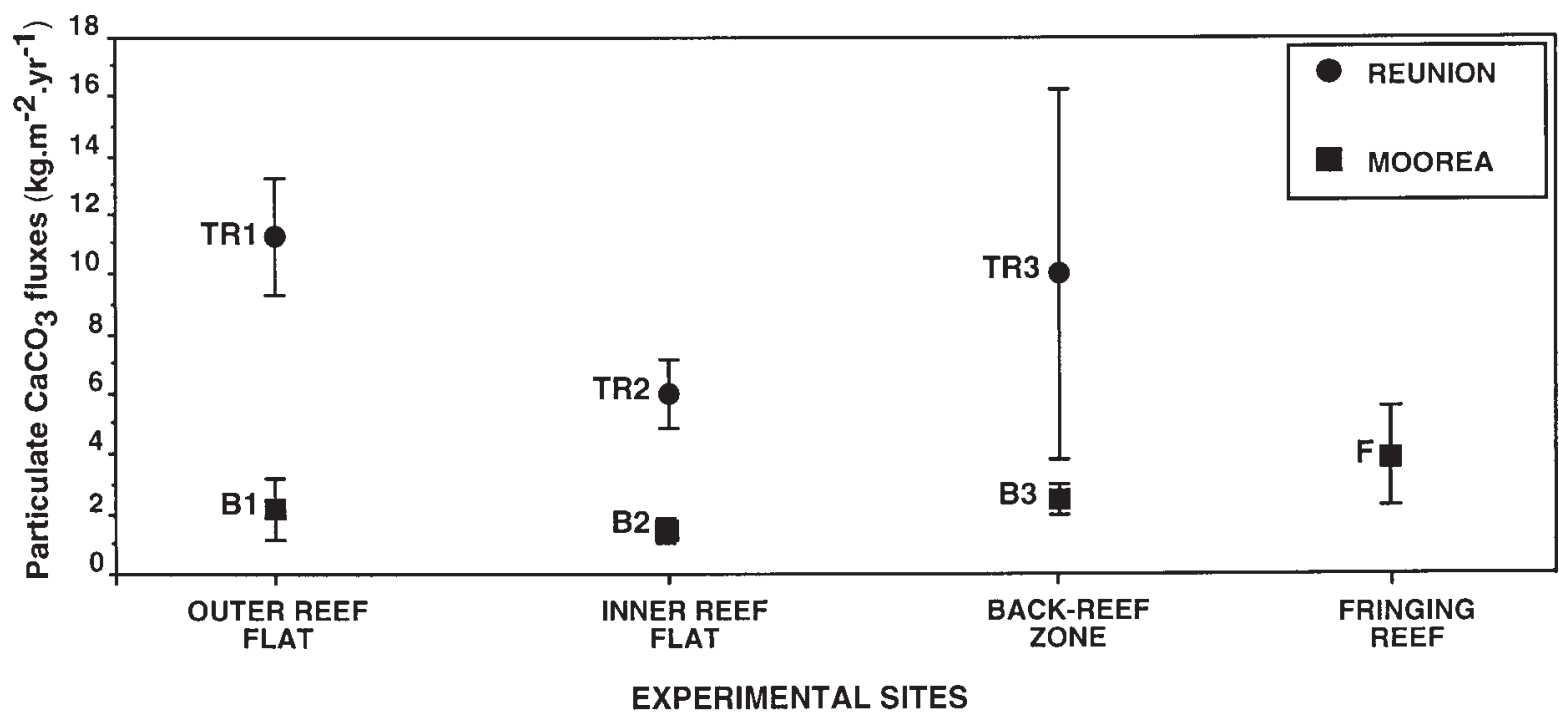

Fig. 4. Mean particulate $\mathrm{CaCO}_{3}$ fluxes $\left(\mathrm{kg} \cdot \mathrm{m}^{-2} \cdot \mathrm{yr}^{-1}\right)$ and standard deviation. Comparison between La Réunion and Mooréa reefs. Experimental sites on La Réunion fringing reef: TR1 (outer reef flat), TR2 (inner reef flat) and TR3 (back-reef zone), and on Mooréa reef: B1 (outer reef flat), B2 (inner reef flat) and B3 (back-reef zone) on the barrier reef and F on the fringing reef. 
inner reef flat, net calcification is high $\left(16-29 \mathrm{~g} \mathrm{CaCO}_{3}\right.$ $\mathrm{m}^{-2} \mathrm{~d}^{-1}$ ), but between the inner reef flat and the backreef, the yearly budget shows dissolution: $-1.5 \mathrm{~kg}$ $\mathrm{CaCO}_{3} \cdot \mathrm{m}^{-2} \mathrm{yr}^{-1}\left(1-9 \mathrm{~g} \mathrm{CaCO}_{3} \mathrm{~m}^{-2} \mathrm{~d}^{-1}\right)$.

On Mooréa, the budget between the outer reef flat and the back reef (Gattuso, Pichon, Delesalle, Canon \& Frankignoulle 1996), indicates a net calcification of $18 \mathrm{~g} \mathrm{CaCO}_{3} \mathrm{~m}^{-2} \mathrm{~d}^{-1}$.

\section{Particulate $\mathrm{CaCO}_{3}$ fluxes}

Particulate $\mathrm{CaCO}_{3}$ fluxes were studied on La Saline transect (La Réunion) and on Tiahura transect (Mooréa). Sampling of sediments was carried out using trapping of grains moving in suspension across the reef. This method allows us to quantify the particulate carbonate fluxes and to define the relative contributions of the various components (corals, coralline algae, foraminifera, molluscs etc.). These analyses were performed only on samples collected during calm sea periods in order to avoid reworked sediment.

Quantification of particulate $\mathrm{CaCO}_{3}$ fluxes

On La Saline transect, particulate $\mathrm{CaCO}_{3}$ fluxes vary between $6.0 \pm 1.1 \mathrm{~kg} \cdot \mathrm{m}^{-2} \cdot \mathrm{yr}^{-1}$ on the inner reef flat (TR2) and $11.3 \pm 2.0 \mathrm{~kg} \cdot \mathrm{m}^{-2} \cdot \mathrm{yr}^{-1}$ on the outer reef flat (TR1) (Fig. 4).

On the Mooréa transect, measured particulate $\mathrm{CaCO}_{3}$ fluxes are significantly lower, particularly on the barrier reef $\left(2.2 \pm 1.0 \mathrm{~kg} \mathrm{CaCO} \cdot \mathrm{m}^{-2} \cdot \mathrm{yr}^{-1}\right.$ on $\mathrm{B} 1$, $1.4 \pm 0.4 \mathrm{~kg} \mathrm{CaCO} \cdot \mathrm{m}^{-2} \cdot \mathrm{yr}^{-1}$ on $\mathrm{B} 2$ and $2.5 \pm 0.5 \mathrm{~kg}$ $\mathrm{CaCO}_{3} \mathrm{~m}^{-2} \cdot \mathrm{yr}^{-1}$ on B3). The highest flux recorded on the Mooréa transect concerns the flinging reef: $4.1 \pm 1.5$ $\mathrm{kg} \mathrm{CaCO}{ }_{3} \cdot \mathrm{m}^{-2} \cdot \mathrm{yr}^{-1}$.

\section{Composition of trapped sediments}

The sediments collected by traps on La Saline and on Tiahura transects revealed large amounts of coral and calcareous algae debris, these components totalling between 63 and $85 \%$ of the total composition. However, major differences have been found between $\mathrm{La}$ Réunion and Mooréa sediments. Whereas La Réunion sediments are characterized by the prevalence of calcareous algae debris (between 40 and 55\% of total composition) over coral detritus (32-46\%), Mooréa samples exhibited higher contributions of coral debris (32-46\%) and a better balance between the two major components (Fig. 5).

Debris of molluscs and echinoderms have been found in every sample but with respective contributions generally higher in Mooréa samples (9-14\% molluscs and 4-7\% echinoderms) than in La Réunion

\section{REUNION}

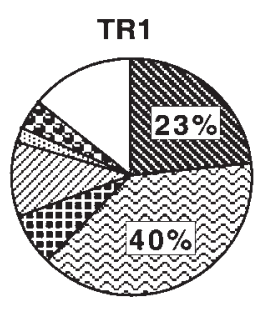

TR2

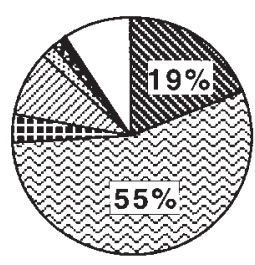

TR3

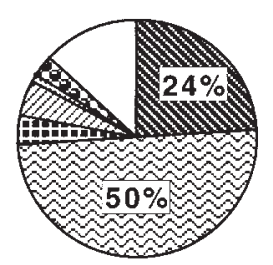

CORALS
cALCAREOUS ALGAE
ENCRUSTING BENTHIC FORAMINIFERA
MOLLUSCS
CRUSTACEANS
ECHINOIDS
SPONGES
otHERS (free benthic foraminifera,
alcyonarians, serpulids, unknown)

alcyonarians, serpulids, unknown)

Fig. 5. Composition of trapped sediments on La Réunion and on Mooréa reefs. Experimental sites on La Réunion fringing reef: TR1 (outer reef flat), TR2 (inner reef flat) and TR3 (back-reef zone) and on Mooréa reef: B1 (outer reef flat), B2 (inner reef flat) and B3 (back-reef zone) on the barrier reef and $\mathrm{F}$ on the fringing reef.

sediments (5-10\% molluscs and less than 4\% echinoderms). The outer reef of Mooréa excepted, a similar tendency could be observed for encrusting foraminifera (3-6\% in La Réunion sediments and 9-21\% elsewhere on the Tiahura transect).

Only sediments collected on La Saline transect contained sponge spicules (less than 3\% of the total composition). The other components (crustaceans, free benthic foraminifera, bryozoans etc.) are of minor importance since their relative contribution is generally less than $2 \%$, and they are lacking in several samples.

As a summary, even though the sediments collected by traps are wholly dominated by coral and calcareous algae debris on both reefs, major differences were 
found between the La Réunion and Mooréa samples. First, particulate carbonate fluxes are significantly higher in La Réunion than in Mooréa and, second, a large prevalence of calcareous algae debris is characteristic of La Réunion sediments, whereas contributions of corals and calcareous algae are almost balanced in Mooréa samples.

Our data relative to benthic communities and to bioerosion are not sufficient to explain the differences between the two reefs. Only a close study of the benthic communities (cover rates, susceptibility to bioerosion) and the bioeroder communities (composition, erosion rates, trophic behaviour) will reveal the precise relationships between carbonate production and deposition.

\section{Conclusions}

The first results obtained in this study seem to indicate that these two reefs have at the same time a high positive budget of calcification/dissolution and an important external erosion resulting from grazer activity. Although a high percentage of the $\mathrm{CaCO}_{3}$ precipitated on the reefs is therefore eroded, calcification appears to be adequate to sustain some reef growth. The significant difference between these two reefs appears in the particulate carbonate fluxes and in the composition of the trapped sediments. Perhaps it may be possible to explain these differences by the composition of grazer communities.

On Mooréa, erosion by grazing results principally from the activity of three species of sea urchins and also of scariid fishes, whereas on La Réunion only one species of grazer is very active in bioerosion .

\section{Dansk sammendrag}

Bioerosionsprodukter af mikro- og makroborende og grassende organismer på koralrev består af partikulært og opløst karbonat. De større borende og grassende arters bidrag til bioerosion blev beregnet for Fransk Polynesien og La Réunion. Bioersionens indflydelse på budgettet for karbonatudskillelse og -opløsning samt partikulær kalciumkarbonat flux blev undersøgt.

\section{References}

Chazottes, V. 1994: Etude expérimentale de la bioerosion et de la sédimentogénèse en milieu récifal: effet de l'eutrophisation (Île de La Réunion, Océan Indien occidental). Doctoral thesis, Aix-Marseille I, 285 pp.

Chazottes, V., Le Campion-Alsumard, T. \& Peyrot-Clausade, M. 1995: Bioerosion rates on coral reefs: interactions between macroborers, microborers and grazers
(Mooréa, French Polynesia). Palaeogeography, Palaeoclimatology, Palaeoecology 113, 189-198.

Conand, C., Chabanet, P., Cuet, P. and Letourneur, Y. 1997: The carbonate budget of a fringing reef in La Réunion Island (Indian Ocean): sea urchin and fish bioerosion and net calcification. Proceedings of the 8th International Coral Reef Symposium 1, 953-958. Panama.

Conand, C., Heeb, M., Peyrot-Clausade, M. \& Fontaine, M. F. in press: Evaluations of bioerosion by two types of sea urchin Echinometra mathaei, on several sites of a fringing reef in La Réunion island (Indian Ocean) and comparison with other sites. In Mooi, R. \& Telford, M. (eds.) Echinoderms 609-615. Balkema, Rotterdam.

Gattuso, J. P., Pichon, M., Delesalle, B. Canon, C. \& Frankignoulle, M. 1996: Carbon fluxes in coral reefs. I. Lagrangian measurement of community metabolism and resulting air-sea $\mathrm{CO}_{2}$ disequilibrium. Marine Ecology Progress Series 145, 109-121.

Pari, N. 1998: Les éponges perforantes dans les milieux récifaux actuels et anciens: significations écologiques et paléoécologiques. Thesis of the University of Provence, 201 pp.

Peyrot-Clausade, M., Le Campion-Alsumard, T., Hutchings, P., Le Canpion, J., Pari, N. \& Fontaine, M. F. 1995: Initial bioerosion and bioaccretion on experimental substrates in high island and atoll lagoons. Oceanologica Acta 18, 531-541.

Smith, S. \& Kinsey, D. W. 1978: Calcification and organic carbon metabolism as indicated by carbon dioxide. In Stoddart, D. R. \& Jenkins, R. E.(eds.) Coral Reefs: Research Methods. UNESCO Monographs on Methodology, 5, 469-484 